\title{
PARAMETRIC DESIGN ANALYSIS AND FEA SIMULATION OF A CHISEL PLOW FOR AN AGRICULTURE USE
}

\author{
Pawan Sharma ${ }^{1}$ and Prof. (Dr.) Manish Bhargava ${ }^{2}$ \\ ${ }^{1,2}$ Department of Mechanical Engineering \\ ${ }^{1,2}$ Maharishi Arvind Institute of Engineering and Technology, Jaipur, India
}

\begin{abstract}
CAD Software for the structural analysis is basically used for the application of CAD/CAM in design optimization of tillage tools, which is based on the simulation method and Finite Element Method. The various components of the tillage tools are simulated with help of actual field performance rating parameters which are prepared by solid models along with actual boundary conditions. The planned work outcomes of sufficient tolerance in varying the working parameters of Chisel Plow sections for ejecting the extra weight in a solid section and also to increase the weight of plow for a consistent potency.

In this paper parametric study of two different kinds of Chisel Plow for an agriculture use in designing from stress, strain, deformation and fatigue analysis has done. One is Old Chisel Plow \& another is New Generation Chisel Plow. The old working model of Chisel Plow is compared with new design parameters with change of its geometry for the maximum weed exclusion efficiency by showing its realistic results from the actual field performance.
\end{abstract}

\section{KEYWORDS}

Stress, Strain, Deformation, Fatigue, Modeling, Analysis \& Shape Optimization.

\section{INTRODUCTION}

The development of field is very costliest process in farming. It includes forest cleaning, soil aperture using bottomless tillage tools, movements of soil from high to low places, farm road construction, land leveling etc. These all operations can be performed by using self propelled and heavy equipments such as crawler tractors, high horsepower tractors, scrapers, ditchers, chisel ploughs, levelers etc. To gain the required seedbed to provide optimal atmosphere for start germination and plant development, mechanical exploitation of soil is required, known as tillage operations and for minimize the design optimization and manufacturing errors of the components, design analysis and optimization is necessary.

Particularly blades and spread parts must be consistent in field the concert against to working conditions. Forecasting of Stress Analysis must be required for manufacturers, designers and researchers. The optimization in design of a chisel plow can be obtained by decreasing its weight, cost and by improving the weed exclusion rate. In industries, CAD software's are used for the designing the desired model and FEA software's are used for the solid analysis of the model. Thus after the analysis of stress, strain, safety factor, displacement, fatigue etc. on FEA software, the simulation results shown in terms of safe results or in terms of breakdown and failure due to high stresses and deformation.

The planned work shows an experimental way for model testing and validation of agriculture tools and equipments. The selected model of a chisel plow is measured with actual dimensions and its solid model is prepared on Autodesk Inventor 2014 and the simulation is done on ANSYS v14.5. ${ }^{[1]}$ 


\subsection{Types of Chisel Plows}

- Animal Drawn Mouldboard

- Melur

- Bullock Drawn Disc Harrow

- Improved Iron

- Animal Drawn Bose

- Disc Harrow

- Khargaon

- Blade Harrow

- Dabra

- Bullock Drawn Puddler

- Rau

- Animal Drawn Puddler

- Chisel

- Animal

Drawn Helical Blade

- MP Iron Wedge Puddler

- Birsa Animal Drawn Ridger

- Bullock Drawn Land Leveler

- Kapas Ridger

- Bullock Drawn Cultivator

- Bullock Drawn Ridger

- Tractor Mounted Mouldboard

- Tractor Drawn Disc

These are the various types of Chisel Plows used in agriculture field for different types of soils.

\section{MATERIALS}

The materials are taken from the engineering database of Chisel Plow production system specification drawn by Industry. The properties of Material and Soil are taken as per the following data:

Table 1. Material Properties

\begin{tabular}{|c|l|l|}
\hline Material Name & \multicolumn{2}{|c|}{ Stainless Steel } \\
\hline \multirow{4}{*}{ Material Properties } & Density & $7750 \mathrm{Kg} / \mathrm{m}^{3}$ \\
\cline { 2 - 3 } & Young's Modulus & $1.93 \times 10^{11}$ \\
\cline { 2 - 3 } & Poisson Ratio & 0.31 \\
\cline { 2 - 3 } & Bulk Modulus & $1.693 \times 10^{11}$ \\
\cline { 2 - 3 } & Shear Modulus & $7.3664 \times 10^{10}$ \\
\cline { 2 - 3 } & Tensile Yield Strength & $207 \mathrm{MPa}$ \\
\cline { 2 - 3 } & Compressive Yield Strength & $207 \mathrm{MPa}$ \\
\cline { 2 - 3 } & Tensile Ultimate Strength & $586 \mathrm{Mpa}$ \\
\hline
\end{tabular}

Table 2. Soil Properties

\begin{tabular}{|c|c|c|c|}
\hline S. No. & Type of Soil & $\begin{array}{c}\text { Soil Resistance } \\
\left(\mathrm{Kg} / \mathrm{m}^{2}\right)\end{array}$ & $\begin{array}{c}\text { Optimum Moisture } \\
\text { Content (\%) }\end{array}$ \\
\hline 1 & Sandy Soil & 2000 & 3.5 \\
\hline 2 & Sandy Loam & 3000 & 5.8 \\
\hline 3 & Silt Loam & $3500-5000$ & 5.8 \\
\hline 4 & Clay & $4000-5600$ & 7.18 \\
\hline 5 & Heavy Loam & $5000-7000$ & 13.30 \\
\hline
\end{tabular}




\subsection{Soil Parameters}

The properties of the soil related to the desired chisel plow were recognized as types of soil, wetness, mass concentration and cone index. The measurement and categorization methodologies are discussed in the subsequent section. Black type of soil is used in this research work for the chisel plow analysis. The humidity substance of soil performs a significant task for the development of the crops therefore subsequent Soil resistance and humidity substance of soil are taken as per the table $2 .{ }^{[6]}$

\section{MODELING AND DESIGNING METHODS}

The modeling and designing methods include the number of various parameters, methods and steps for model construction. The input boundary conditions will be required for the pre processing stage of the desired chisel plow.

\subsection{Finite Element Method for Chisel Plow}

The useful features of finite element methods are as follows ${ }^{[7]}$ :

- Discretization of the whole model into small elements, which may be square, rectangle, and triangle or in polygon shapes.

- Derive the governing differential equations for each element of the model.

- Assembly of all elements, based on stability of the solution.

\subsection{Mesh Generation}

The conversion of whole model into number of small elements is known as Mesh generation. The meshing is a very important step for the accurate solution. Various kinds of meshing are used in the pre-processing. We are using the mesh generation with a good number of relevance with fine mesh. For the Chisel Plow elements are used for meshing.

The elements may be rectangular or triangular. We are using triangular mesh for a high accuracy. The number of elements represents the solution accuracy of the model. The elements can be increased by increasing the relevance number. So that the run time is less and also the accuracy is not much affected.

The mesh view of both the Chisel Plows is given below:

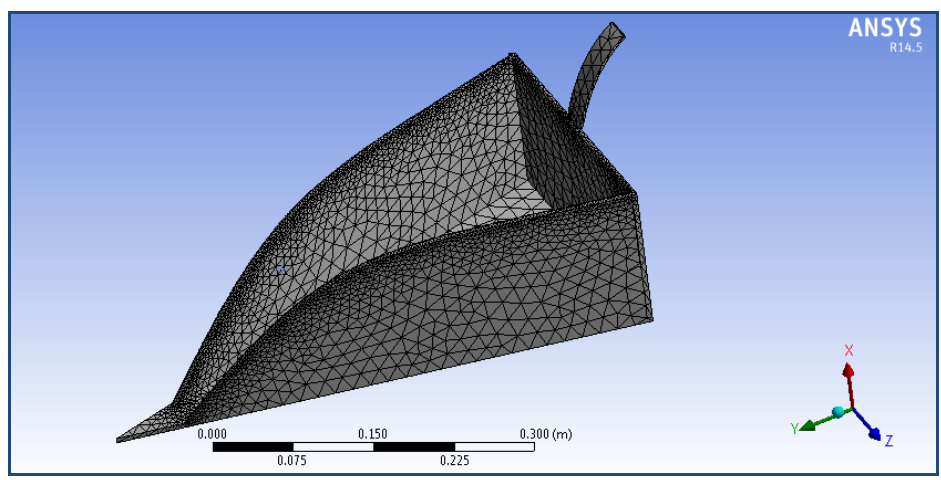

Figure 1. Mesh Pictures of the Old Model of Chisel Plow 


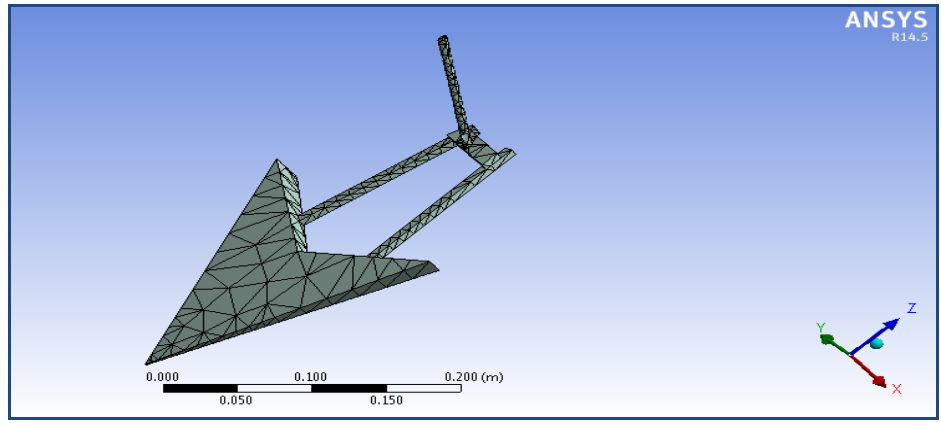

Figure 2. Mesh Pictures of the New Generation Model of Chisel Plow

The fine triangular mesh is showing with scale in the above figures shows the accuracy of mesh at small and large surface areas.

\subsection{Model Description}

The Model Description for the Chisel Plow is given below:

Table 3. Model Description

\begin{tabular}{|l|l|l|l|}
\hline \multicolumn{2}{|c|}{ Old Model of Chisel Plow } & \multicolumn{2}{c|}{ New Generation Model of Chisel Plow } \\
\hline Length X & $0.24281 \mathrm{~m}$ & Length X & $0.10152 \mathrm{~m}$ \\
\hline Length Y & $0.55658 \mathrm{~m}$ & Length Y & $0.23556 \mathrm{~m}$ \\
\hline Length Z & $0.25 \mathrm{~m}$ & Length Z & $0.33916 \mathrm{~m}$ \\
\hline Volume & $\begin{array}{l}1.0423 \mathrm{e}-003 \\
\mathrm{~m}^{3}\end{array}$ & Volume & $2.1013 \mathrm{e}-004 \mathrm{~m}^{3}$ \\
\hline Mass & $8.1817 \mathrm{~kg}$ & Mass & $1.6495 \mathrm{~kg}$ \\
\hline Scale Factor Value & 1 & Scale Factor Value & 1 \\
\hline No. of Nodes & 32105 & No. of Nodes & 1751 \\
\hline No. of Elements & 16472 & No. of Elements & 693 \\
\hline
\end{tabular}

The model description shows in the above table number 3. The model description shows the exact location and orientation of the model with respect to the global coordinate system. The model description includes the model length in $\mathrm{X}, \mathrm{Y} \& \mathrm{Z}$ direction, Volume \& Mass of model, No. of Nodes \& Elements in the model of Chisel Plow after meshing.

\section{ANALYSIS OF CHISEL PLOW BY USING ANSYS}

The Analysis of the model can be done by using boundary conditions. After applying the boundary conditions, we can get the required results. Analysis can be done by using the analysis tool. The Modeling tool is Autodesk Inventor 14 and Analysis tool is ANSYS Workbench 14.5. There are three steps in ANSYS working procedure used for the analysis are:

- Preprocessing

- Solution

- Post processing 
After preparing a solid geometry of Chisel Plow in Autodesk Inventor 14 the important steps are meshing (that we have already done) and applying load on inclined face of the Chisel Plow by the soil and boundary conditions in the preprocessor, so that simulation can be run to get a solution and generate results in the post-processor.

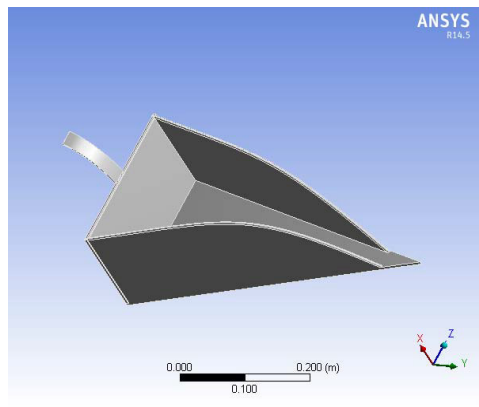

Figure 3(a). Old Model of Chisel Plow

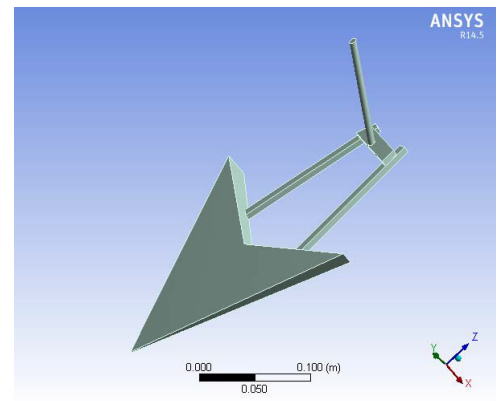

Figure 3(b). New Model of Chisel Plow

The above figure shows the modeled view of Chisel Plow on the modeling tool Autodesk Inventor 14. Figure 3(a) showing the Old Model of Chisel Plow and Figure 3(b) showing New Generation Model of Chisel Plow.

\subsection{Boundary Conditions and Input Parameters}

The boundary conditions are type of supports and forces on various faces, also various supports \& forces are the input parameters for the Chisel Plow.

\subsubsection{Type of Support}

Fixed Support will be applied on the face on which the body experiences the resisting force. Thus, Fixed Support will be applied at the handle of ploughs of both Old Plough \& New Generation Plough.

\subsubsection{Force}

The Force will be applied by the soil in the opposite direction of motion. Thus, the force will be applied on the inclined face of both Old Plough \& New Generation Plough.

Table 4. Force Description

\begin{tabular}{|c|c|}
\hline X Component & $500 \mathrm{~N}$ \\
\hline Y Component & $0 \mathrm{~N}$ \\
\hline Z Component & $500 \mathrm{~N}$ \\
\hline
\end{tabular}

The above boundary conditions are used for modeling and analysis of the Chisel Plow. 


\subsection{Types of Analysis}

We will use total three types of Analysis for both the Chisel Plows under the fix ranges:

\subsubsection{Stress Analysis}

At the same magnitude of force and fixed support, the stress analysis is:

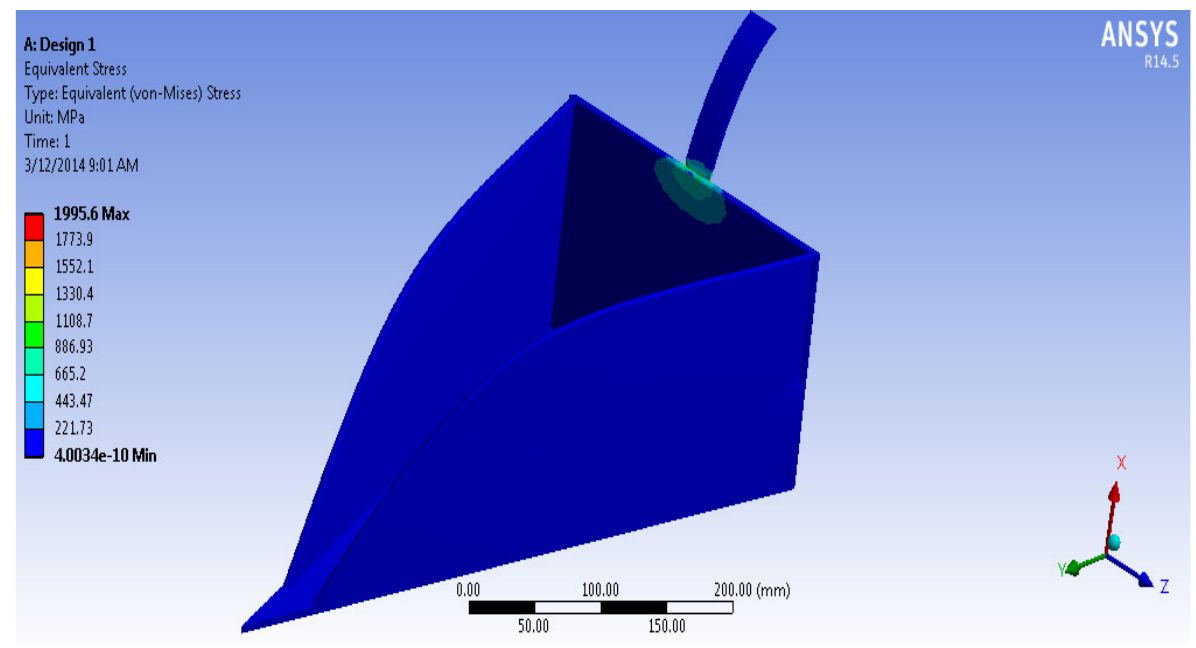

Figure 4(a). Old Model of Chisel Plow

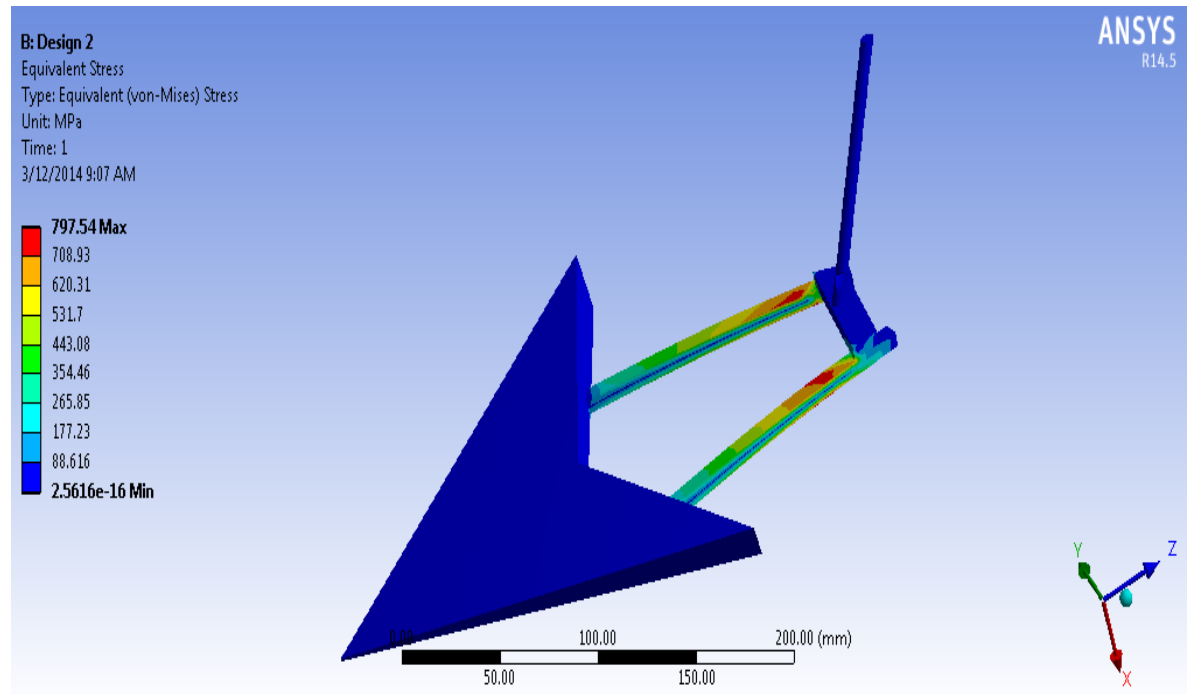

Figure 4(b). New Generation Model of Chisel Plow

Above Figure 4(a) shows Old Model of Chisel Plow, in which under the action of the force of 500 $\mathrm{N}$, the maximum stress is 1995.6 MPa and Figure 4(b) shows New Generation Model of Chisel Plow in which the maximum stress is 797.54 MPa. Thus at the same magnitude of force the lower stress developed in the New Generation Model of Chisel Plow, hence it is safe then the Old Model of Chisel Plow. 


\subsubsection{Strain Analysis}

At the same magnitude of force and fixed support, the strain analysis is:

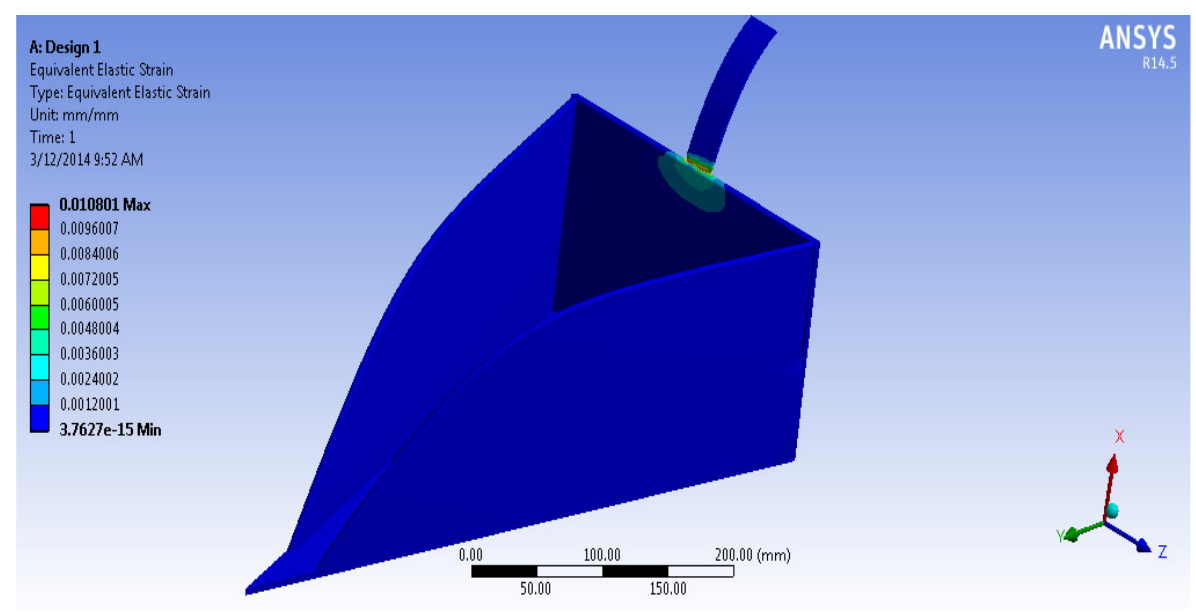

Figure 5(a). Old Model of Chisel Plow

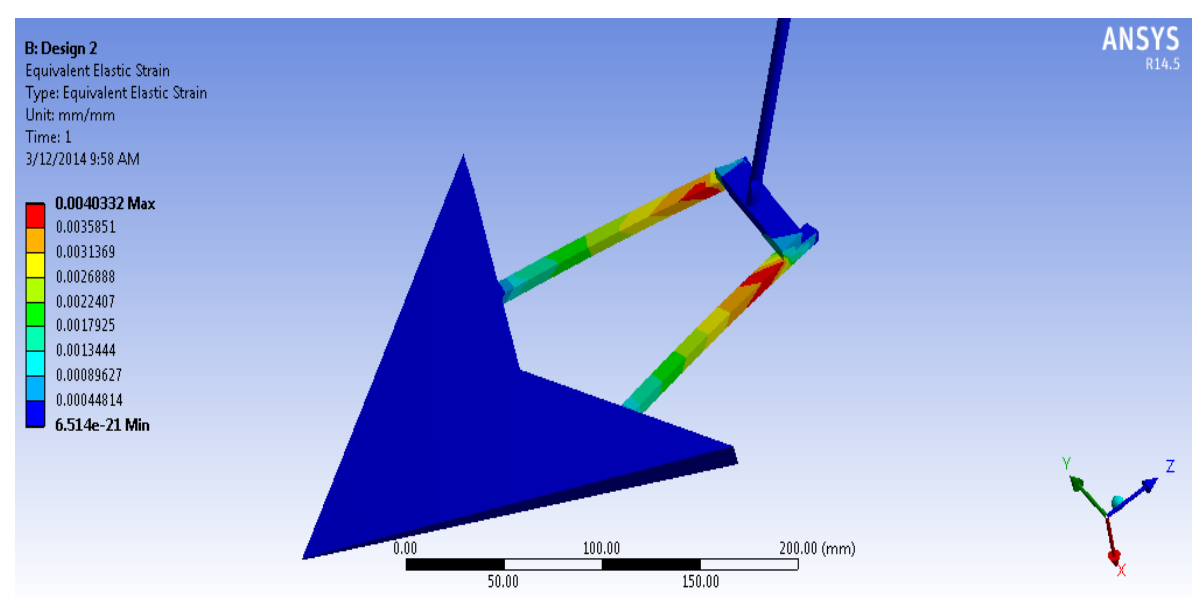

Figure 5(b). New Generation Model of Chisel Plow

Above Figure 5(a) shows Old Model of Chisel Plow, in which under the action of the force of 500 $\mathrm{N}$, the maximum strain is $\mathbf{0 . 0 1 0 8 0 1}$ and Figure 5(b) shows New Generation Model of Chisel Plow in which the maximum strain is $\mathbf{0 . 0 0 4 0 3 3 2}$. Thus at the same magnitude of force the lower strain developed in the New Generation Model of Chisel Plow, hence it is safe then the Old Model of Chisel Plow. 


\subsubsection{Deformational Analysis}

At the same magnitude of force and fixed support, the deformation analysis is:

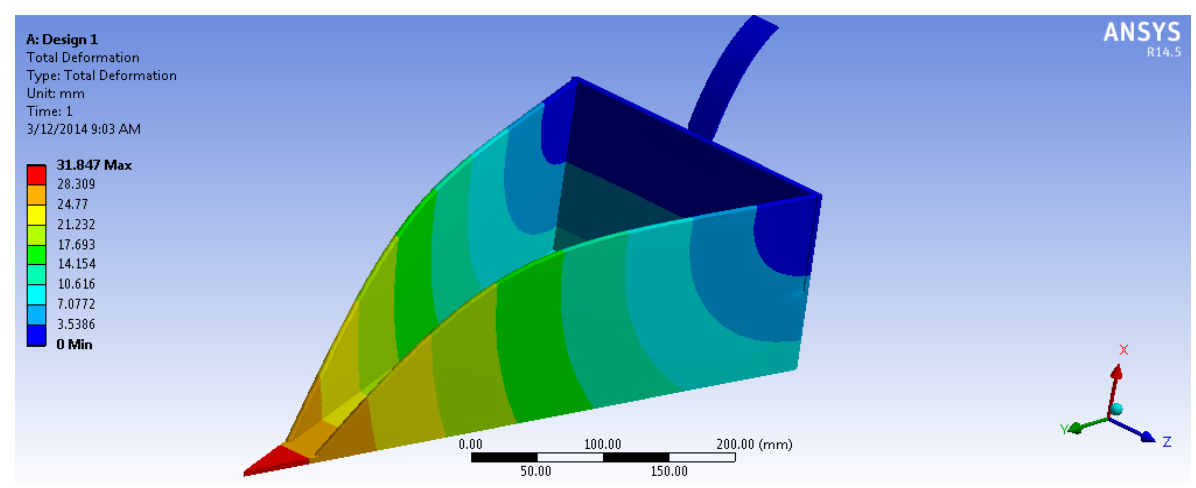

Figure 6(a). Old Model of Chisel Plow

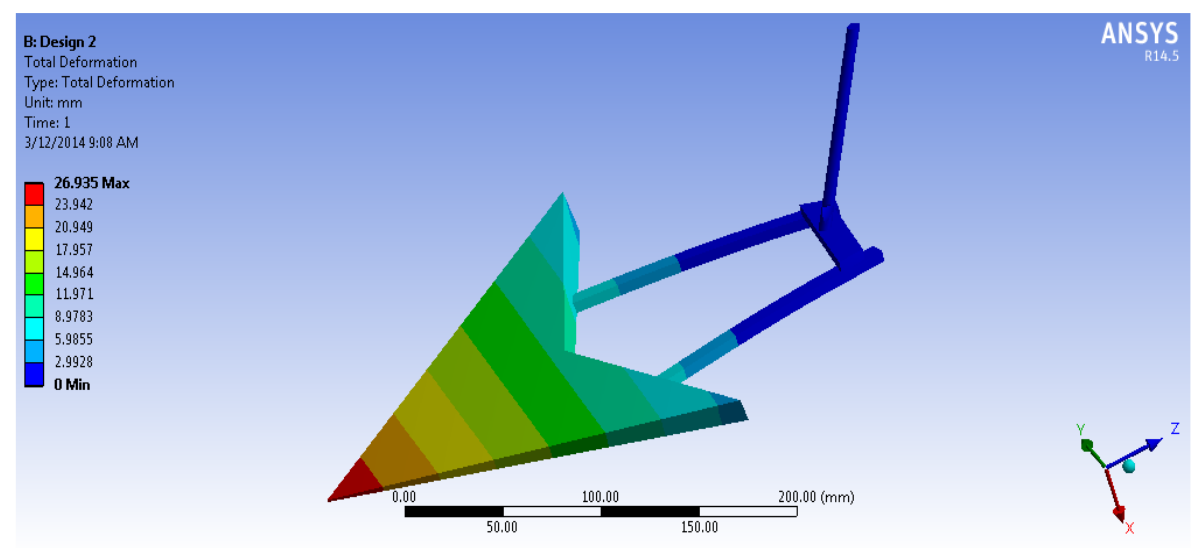

Figure 6(b). New Generation Model of Chisel Plow

Above Figure 6(a) shows Old Model of Chisel Plow, in which under the action of the force of 500 $\mathrm{N}$, the maximum deformation is $\mathbf{3 1 . 8 4 7} \mathbf{~ m m}$ and Figure 6(b) shows New Generation Model of Chisel Plow in which the maximum deformation is $\mathbf{2 6 . 9 3 5} \mathbf{~ m m}$. Thus at the same magnitude of force the lower deformation developed in the New Generation Model of Chisel Plow, hence it is safe then the Old Model of Chisel Plow. 


\subsubsection{Fatigue Analysis}

At the same magnitude of force and fixed support, the life analysis is:

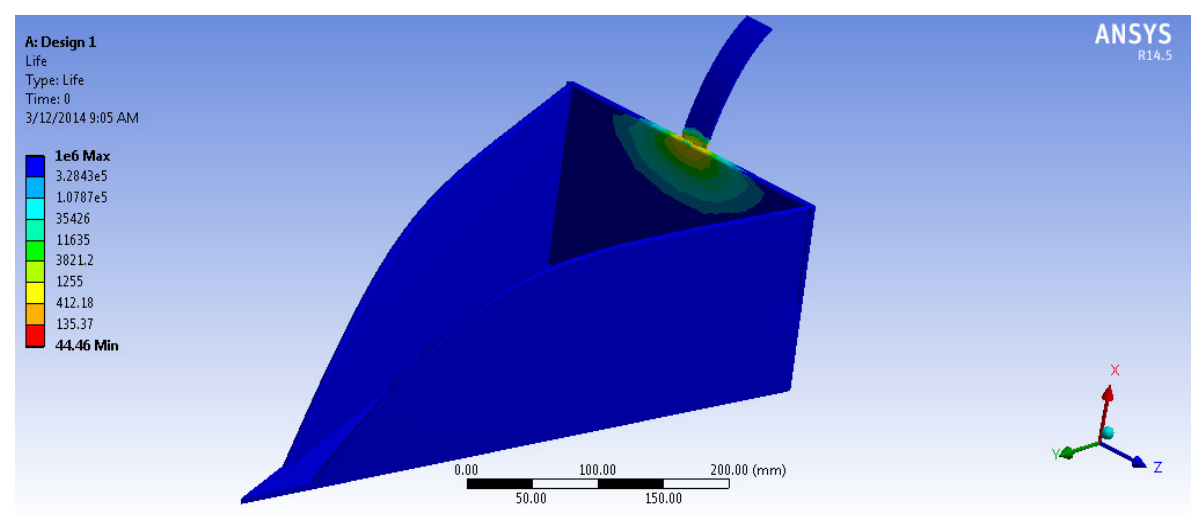

Figure 7(a). Old Model of Chisel Plow

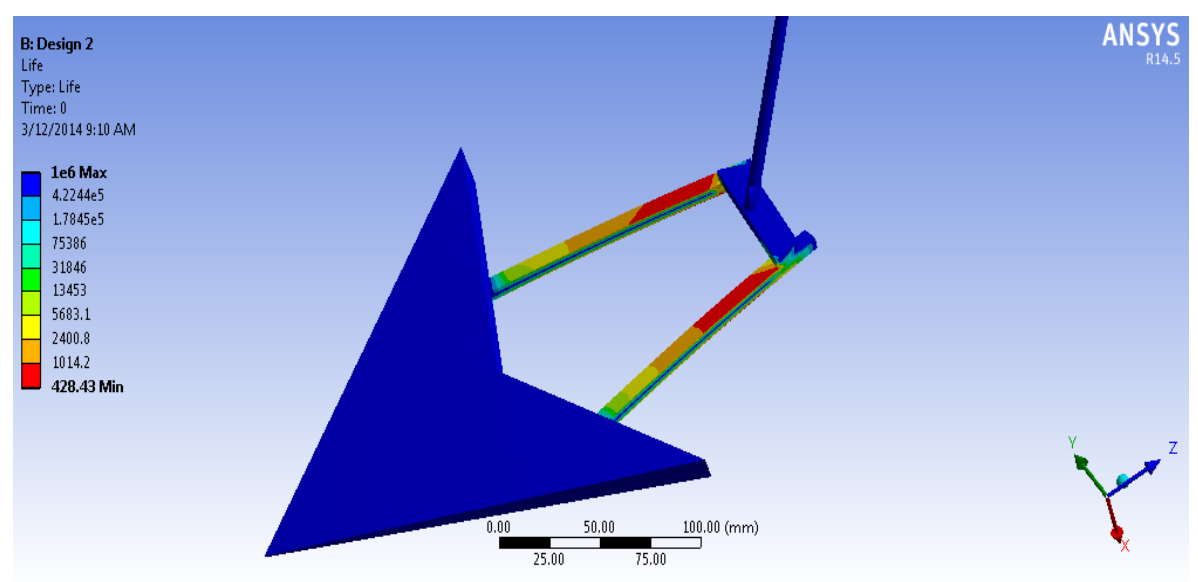

Figure 7(b). New Generation Model of Chisel Plow

Above Figure 7(a) shows Old Model of Chisel Plow, in which under the action of the force of 500 $\mathrm{N}$, the maximum life cycles are 35,426 Cycles and Figure 7(b) shows New Generation Model of Chisel Plow in which the maximum life cycles are 4,22,440 Cycles. Thus at the same magnitude of force the maximum life cycles are in the New Generation Model of Chisel Plow, hence it is safe then the Old Model of Chisel Plow. Thus the above Stress, Strain, Deformation and fatigue analysis of Chisel Plow shows that under the same magnitude of force and fixed constraint the Design of Old Model of Chisel Plow get failed and the Design of New Generation Model of Chisel Plow will safe. 


\section{PARAMETRIC RESULTS}

The parametric results shows the stress, strain, deformation $\&$ fatigue results for old model $\&$ new generation model of Chisel Plow.

\subsection{Stress Results on Chisel Plows}

The Stress result shows in the comparison of Old Model of Chisel Plow and New Generation Model of Chisel Plow.
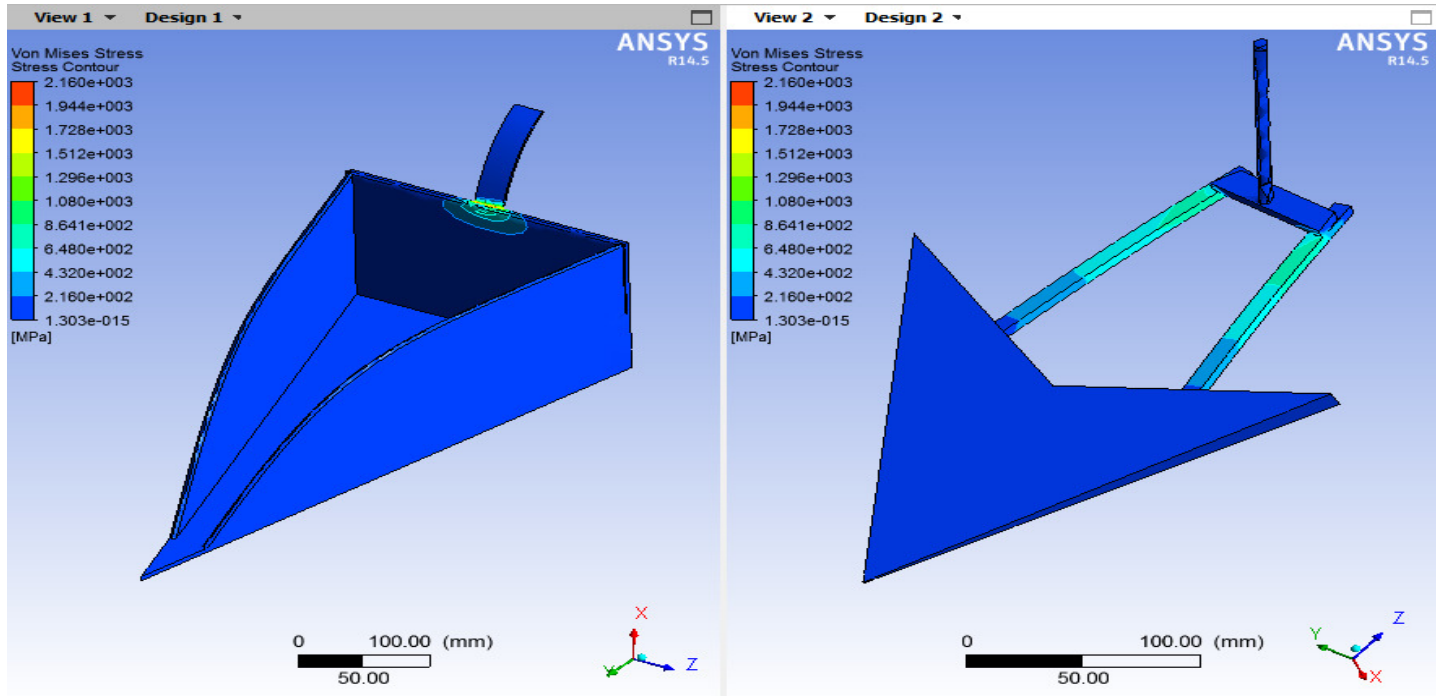

Figure 8. Comparative Stress Results of Both Chisel Plows

Table 5. Stress Results on Chisel Plows

\begin{tabular}{|c|c|c|}
\hline \multicolumn{3}{|c|}{ Von Mises Stresses Results } \\
\hline & Old Model of Chisel Plow & $\begin{array}{c}\text { New Generation Model of Chisel } \\
\text { Plow }\end{array}$ \\
\hline $\begin{array}{c}\text { Maximum } \\
\text { Stress (MPa) }\end{array}$ & 1995.6 & 797.54 \\
\hline $\begin{array}{c}\text { Minimum Stress } \\
(\mathrm{MPa})\end{array}$ & $4.0034 \times 10^{-10}$ & $5.5616 \times 10^{-16}$ \\
\hline
\end{tabular}

Thus, the stress result shows that at the same magnitude of force, the maximum von mises stress developed in Old Model of Chisel Plow is 1995.6 MPa and in New Generation Model of Chisel Plow is 797.54 MPa.

Thus, the Old Model of Chisel Plow get failure and New Generation Model of Chisel Plow get safe at the same magnitude of force \& fixed support. 


\subsection{Strain Results on Chisel Plows}

The Strain result shows in the comparison of Old Model of Chisel Plow and New Generation Model of Chisel Plow.
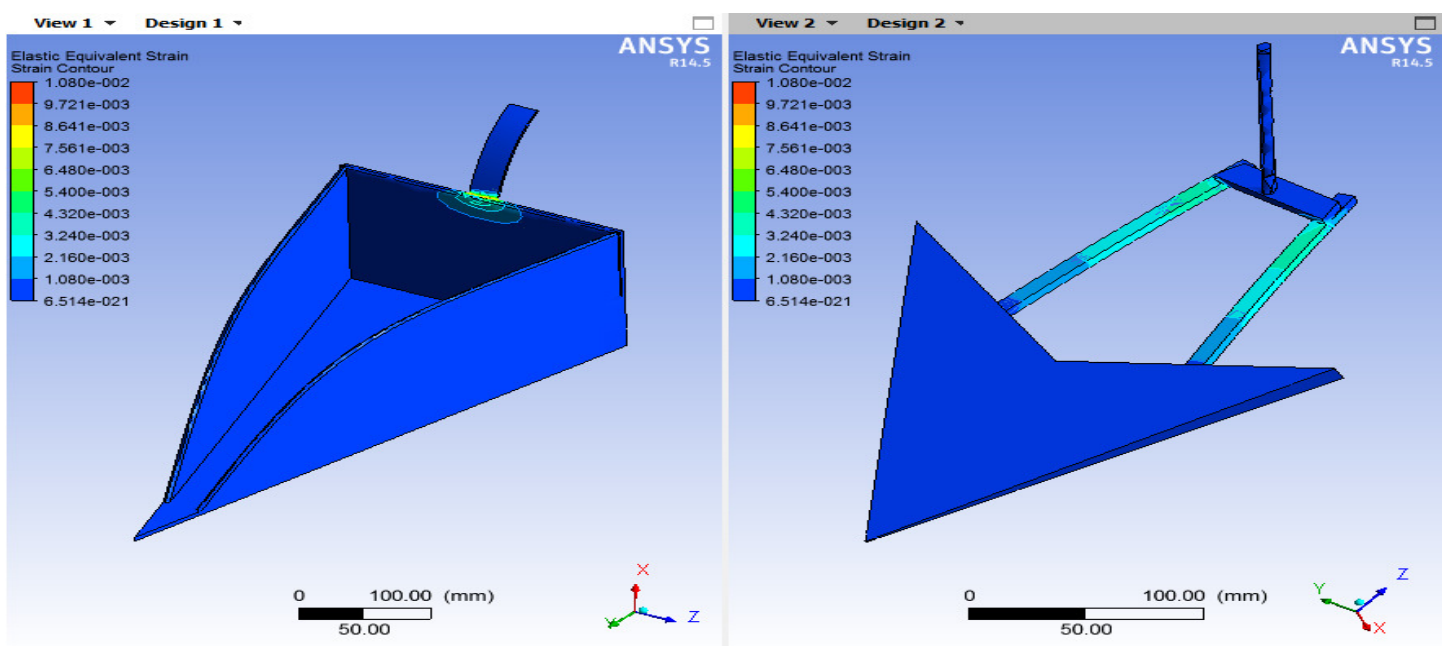

Figure 9. Comparative Strain Results of Both Chisel Plows

Table 6. Strain Results on Chisel Plows

\begin{tabular}{|c|c|c|}
\hline \multicolumn{3}{|c|}{ Elastic Equivalent Strain Results } \\
\hline & Old Model of Chisel Plow & $\begin{array}{c}\text { New Generation Model of Chisel } \\
\text { Plow }\end{array}$ \\
\hline Maximum Strain $(\mathrm{mm})$ & 0.0108 & 0.0040 \\
\hline Minimum Strain $(\mathrm{mm})$ & $3.7627 \times 10^{-15}$ & $6.514 \times 10^{-21}$ \\
\hline
\end{tabular}

Thus, the strain result shows that at the same magnitude of force, the maximum strain developed in Old Model of Chisel Plow is $\mathbf{0 . 0 1 0 8 ~} \mathbf{~ m m}$ and in New Generation Model of Chisel Plow is $0.0040 \mathrm{~mm}$.

Thus, the Old Model of Chisel Plow gets more deformation then New Generation Model of Chisel Plow at the same magnitude of force \& fixed support.

\subsection{Deformation Results on Chisel Plows}

The Deformation result shows in the comparison of Old Model of Chisel Plow and New Generation Model of Chisel Plow. 
International Journal of Recent advances in Mechanical Engineering (IJMECH) Vol.4, No.4, November 2015

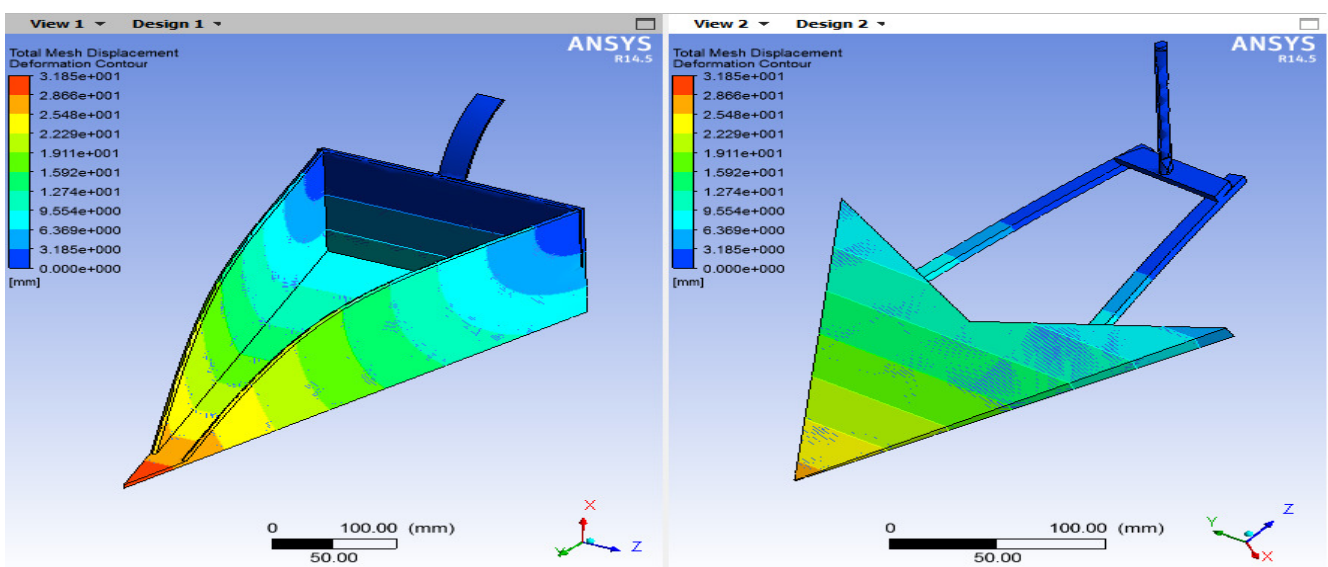

Figure 10. Comparative Deformation Results of Both Chisel Plows

Table 7. Deformation Results on Chisel Plows

\begin{tabular}{|c|c|c|}
\hline \multicolumn{3}{|c|}{ Deformation Results } \\
\hline & Old Model of Chisel Plow & $\begin{array}{c}\text { New Generation Model of } \\
\text { Chisel Plow }\end{array}$ \\
\hline $\begin{array}{c}\text { Maximum } \\
\text { Deformation }\end{array}$ & $31.847 \mathrm{~mm}$ & $26.935 \mathrm{~mm}$ \\
\hline $\begin{array}{c}\text { Minimum } \\
\text { Deformation }\end{array}$ & 0 & 0 \\
\hline
\end{tabular}

Thus, the Deformation result shows that at the same magnitude of force, the maximum strain developed in Old Model of Chisel Plow is $\mathbf{3 1 . 8 4 7} \mathbf{~ m m}$ and in New Generation Model of Chisel Plow is $\mathbf{2 6 . 9 3 5 ~} \mathbf{~ m m}$.

Thus, the Old Model of Chisel Plow gets more deformation then New Generation Model of Chisel Plow at the same magnitude of force \& fixed support.

\subsection{Fatigue Results on Chisel Plows}

The Fatigue result shows in the comparison of Old Model of Chisel Plow and New Generation Model of Chisel Plow.
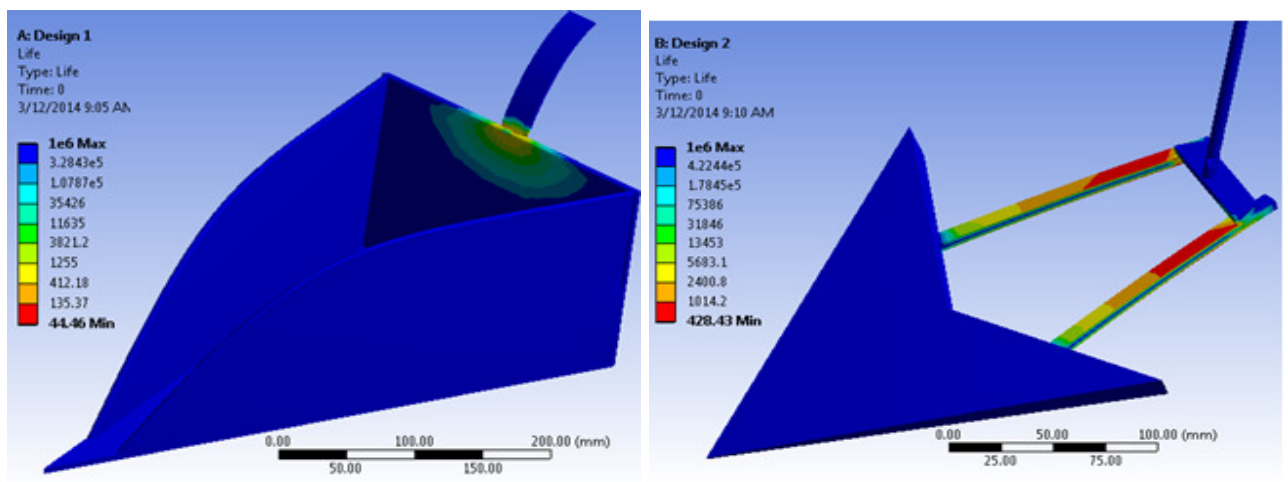

Figure 11. Comparative Fatigue Results of Both Chisel Plows 
Table 8. Fatigue Results on Chisel Plows

\begin{tabular}{|c|c|c|}
\hline \multicolumn{3}{|c|}{ Fatigue Results } \\
\hline & Old Model of Chisel Plow & $\begin{array}{c}\text { New Generation Model of Chisel } \\
\text { Plow }\end{array}$ \\
\hline $\begin{array}{l}\text { Failure Occurs } \\
\text { at }\end{array}$ & 35,426 Cycles & 4,22,440 Cycles \\
\hline
\end{tabular}

Thus, the Fatigue result shows that at the same magnitude of force, the Failure Occurs in Old Model of Chisel Plow is at 35,426 Cycles and in New Generation Model of Chisel Plow is at 4,22,440 Cycles.

Thus, the Old Model of Chisel Plow gets failure then New Generation Model of Chisel Plow at the same magnitude of force \& fixed support.

Thus, the Parametric Results on the basis of Stress, Strain, Deformation and Fatigue Results, the New Generation Model of Chisel Plow is much Safe than the Old Model of Chisel Plow. The design of New Generation Model of Chisel Plow is much safe design for an agriculture use. Also the life of New Generation Model of Chisel Plow is greater than Old Model of Chisel Plow.

\section{CONCLUSION}

A tillage tool such as Chisel Plow is designed in computer aided design software. The motion of Chisel Plow and soil surface interaction is considered. The tillage operations introduces a quality parameters and development scope in obtaining a width of cut, depth of cut, Speed of operation, field efficiency, field capacity, theoretical draft the rate of work, quality of work, draft measurement etc. The analysis of stress, strain, deformation and life cycle shows the safe designs at the same range of input parameters between old model of Chisel Plow and New Generation Model of Chisel Plow.

\section{REFERENCES}

[1] Quirke, S. Scheffler, O. Allen, (1988), "An evaluation of the wear behavior of metallic materials subjected to soil abrasion" Soil and Till. Res. 11

[2] Gill, W.R., and G.E. Vanden Berg, (1996), "Design of tillage tool in soil dynamics in tillage and traction”, 211-294, Washington, D.C.,U.S.GPO

[3] Godwin, R.J. (1982), "Force measurement on tillage implements" 9th Conference of the International soil Tillage Research organization, Osijek

[4] Jain, S.C., and Philip (2003), "Farm machinery an approach, standard publishers distributors Delhi pp. $5-7,21,27$

[5] Kosutic, S., D Filipovic, and Z Gospodaric. (1996), "Rotary Cultivator Energy Requirement Influenced by Different Constructional Characteristics", Velocity and Depth of Tillage. Poljoprivredna-Znanstvena-Somatra, vol 61,Pg3-4, 1996, p 239

[6] Krutz, G., L. Thompson and C. Poul (1984), "Design of Agricultural machine", John Willey and Sons, New Delhi. pp.32-36

[7] Ben Yahia, Logue, and M. Khelifi. (1999), "Optimum settings for rotary tools used for on-the-row mechanical cultivation in corn", Transactions of ASAE, 15(6): 615-619

[8] Biswas, H.S. (1993)., "Performance Evaluation and optimization of straight blades for shallow tillage and weeding in black soils", Agric. Mech. in Asia, Africa and Latin America, 24(4) 19-22

[9] Block, J.M. (1986), "Performance of power tiller blades", Agric. Mech. In Asia, Africa and Latin America, 17 (1): 22-26

[10] Spoor. G., "Design of soil engaging implements", practice, Farm Machine design Eng J:1419,Dec, 1969 
International Journal of Recent advances in Mechanical Engineering (IJMECH) Vol.4, No.4, November 2015

[11] Thakur T.C., (1991), "Design aspects of soil engaging hand tools", Agricultural Engineering Today.21:15-18

[12] Zhang, J., and R.L.K Khuswala, (1996), "Wear and draft of cultivator sweep with hardened edges", Canadian Agricultural Engineering, 37(1); 41-47

\section{AUTHORS:}

Pawan Sharma has completed his B.Tech in Mechanical Engineering, M.Tech in Machine Design from RTU (Kota), Rajasthan, INDIA. He has published more than 25 research papers in the refereed International journals and conferences. He has published three Engineering Books in the field of FEA/FEM. His area of research includes CAD/CAM, FEA/FEM, Composite Materials, CFD and Vibration Analysis.

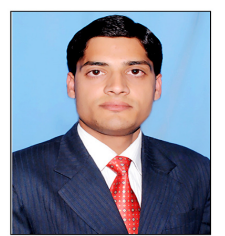

Prof. (Dr.) Manish Bhargava holds M.Tech. in Manufacturing System Engineering, Ph.D. in Mechanical Engineering from MNIT, Jaipur. He has published more than 30 research papers in the refereed International journals and conferences. He has a teaching and research experience of more than 14 years. Currently, He is working as a Professor in Mechanical Engineering \& Principal with Maharishi Arvind Institute of Engineering and Technology, Jaipur, Rajasthan, India. His area of research includes CIMS, CAD/CAM, Reliability \& Maintenance, Manufacturing Systems and Material

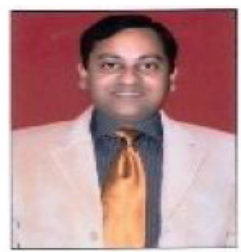
Science. 